\title{
Phylogeny of Marine Ornamental Fish Members of Labridae from the South Coast of West Java, Indonesia
}

\author{
DION SATRIO PAMBUDI ${ }^{1}$, AGUS NURYANTO $^{1 *}$, ROMANUS EDY PRABOWO $^{1}$ \\ ${ }^{1}$ Faculty of Biology, Universitas Jenderal Soedirman \\ Jl. Dr. Soeparno No. 63 Grendeng, Purwokerto, Central Java, Indonesia. 53122 \\ *Email: agus.nuryanto@unsoed.ac.id
}

Received 29 August 2019; Received in revised form 04 September 2019;

Accepted 01 December 2019; Available online 30 December 2019

\begin{abstract}
Labridae is a large and diverse fish family. Many species under Labridae inhabits Indonesian coral reefs. However, limited scientific data are available on ornamental fish diversity in Labridae from the South Coast of West Java, Indonesia. The purpose of the research is to give information about species diversity and phylogenetic relationships among species of Labridae fish family in the South Coast of West Java. This research will be conducted using a survey method with a purposive sampling technique. The observed parameters include morphometric and meristic characters and evolutionary relationships among species within Labridae family species collected from the South Coast of Sukabumi and Garut, West Java. Morphological data will be analyzed descriptively based on morphometric and meristic data. Species-level identification performed by referring to the available identification guide book. Phylogenetic relationships will be analyzed statistically using cladistics method as implemented in PAUP 4.0 applying maximum parsimony algorithm. The cladogram has a consistency index of 0.563 , indicating low homoplasy and proved that the tree was the most parsimonious. Labridae formed monophyletic clade compared to Acanthurus maculiceps, and Cheilio inermis was basal species while the others derived species.
\end{abstract}

Keywords: Labridae; meristics; morphometrics; phylogeny

\section{INTRODUCTION}

Every year, millions of marine organisms are exploited from the sea, distributed throughout the world and end up in home aquariums. Most marine organisms are exported to the United State America (U.S.A), followed by Europe, Japan, and other countries (Smith et al., 2008). The extraction of fish occurs mainly from coral reefs in Coral Triangle Region, which include Pacific countries, Indonesia, Malaysia, Papua New Guinea, Philippines, Solomon Island, and Timor-Leste. Indonesia is the second-biggest exporter of marine ornamental fish after China (Hoeksema, 2007).

Labridae, also known as Wrasses, are the most abundant and conspicuous fishes on tropical reefs around the world. Wrasses also comprise an essential element of the cold water fish population on temperate reefs. They are the second-largest family of marine fishes and the third largest family in the Perciformes order, containing approximately 70 genera and roughly 504 species. Wrasses appear in a diverse range of colors, shapes, and sizes, often varying considerably within individual species (Parenti \& Randall, 2011). Several species in Labridae also become important ornamental fish kept by a hobbyist in their aquaria.

Marine ornamental fish trade in Indonesia mostly supported by natural collection. Other studies also reported that this support comes from marine ornamental fish collected in eastern Indonesia, such as Bali and Makassar. Nevertheless, the study on marine ornamental fish from the south coast of West Java was unavailable, especially on phylogenetic relationships. The available data was only on the potential of marine ornamental fish. Therefore, it is crucial to study the phylogeny of ornamental fish w Labridae from the south coast of West Java with particular reference to Taman Manalusu Garut Regency and Ujung Genteng Sukabumi Regency. The two regions are popular marine ornamental fish trade spots on the south coast of West Java (Mayunar, 1996).

The phylogenetic study can be studied either based on morphological or molecular characteristics. The morphological 
characteristic can be observed based on morphometric measurement and meristic counts (Floeter et al., 2018; Naeem et al., 2011; Sabour et al., 2014). Molecular characteristic studied based various DNA markers; e.g. dloop (Murakami et al., 2001; Sasaki et al., 2007), cytochrome b (Bernal \& Rocha, 2011; Kamarudin \& Esa, 2009; Sorenson et al., 2014), and cytochrome c oxidase 1 (Carpenter et al., 2017; Liu et al., 2013; Santini et al., 2016). Morphology and molecular characteristics had also used in phylogenetic studies of Labridae. The previous study from (Almada et al., 2002) studied phylogenetic affinities between Centrolabrus trutta and $C$. caeruleus based on molecular and meristic characters, whereas, (Arnal et al., 2006) analyzed phylogenetic relationships of Labridae based on body size, body shape, and body-color pattern. Baliga \& Law (2016) studied the phylogeny of Labridae based on four molecular markers. Molecular marker had also used by other authors in phylogenetic studies of Labridae (Beldade et al., 2009; Choat et al., 2012; Smith et al., 2008). None of those studies used ratio between morphometric measure of a specific body part and standard length or ration between morphometric measures of head part to head length, especially on marine ornamental fish from Taman Manalusu Garut and Ujung Genteng Sukabumi in the south coast of West Java.

Here we studied the phylogeny of marine ornamental fish within Labridae to know and provide information evolutionary relationship among species under Labridae family from the South Coast of Sukabumi and Garut, West Java. The information is essential for decision-maker in making policies for sustainable use of marine ornamental fish resources from the South Coast of West Java, especially for fish species within Labridae.

\section{MATERIALS AND METHODS}

Study site. Fish specimen collected from Taman Manalusu Garut Regency and Ujung Genteng Sukabumi Regency (Figure 1). These regions selected based on the previous study from (Mayunar, 1996) that Taman Manalusu and Ujung Genteng had high potential of marine ornamental fish and among trading spots in the south coast of West Java.

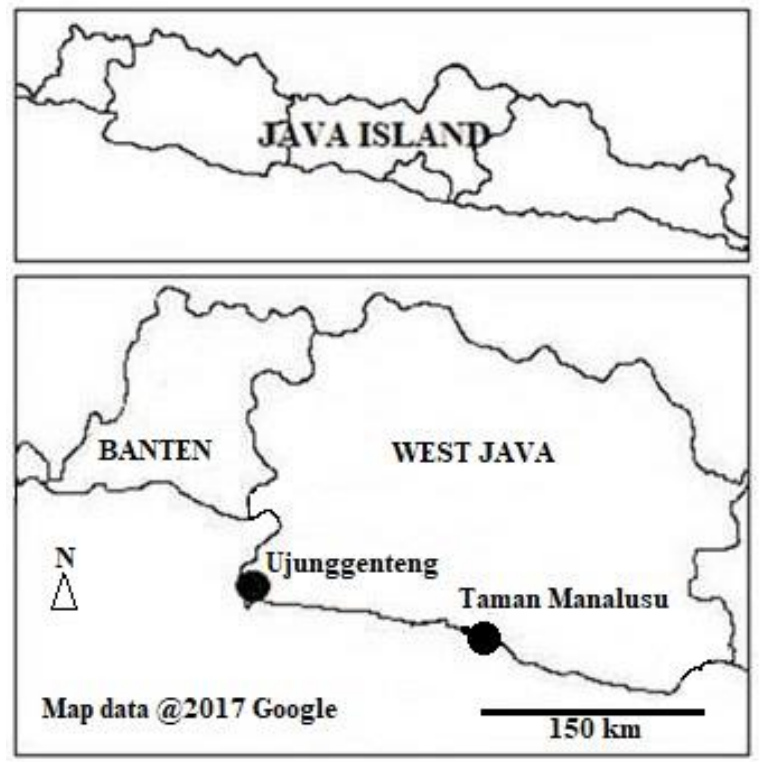

Figure 1. Sampling sites in south coast of West Java, Indonesia

Field trips performed in February, March, and April 2018. Fish samples photographed directly before preservation in ethanol $70 \%$. This step conducted to have original color patterns since that characteristic is among the essential diagnostic characters for species identification. Species identification referred to Allen \& Erdmann (2012). The validity of the scientific name of the specimen checked on FishBase database (Froese \& Pauly, 2019).

Morphological observations conducted on various characters such as biometric, meristics, 
and color patterns in dorsal fin. Morphometric measurement conducted put the individual fish on millimeter block with the head on the left side of the researcher. Morphometric measurements performed in several body parts and head parts. The size obtained divided by standard length for measurement in body part or by head length for the measurement on head parts. Meristics data obtained from counting the number of hard and soft fin rays of the samples. The characters used in phylogenetic analysis of Labridae presented in Table 1.

Table 1. The morphological characteristics used for phylogenetic analysis of Labridae

\begin{tabular}{ccc}
\hline No & Character & Remarks \\
\hline $\mathbf{1}$ & BD:SL & Ratio body depth to standard length \\
$\mathbf{2}$ & DL:SL & Ratio dorsal fin length to standard length \\
$\mathbf{3}$ & VL:SL & Ratio ventral fin length to standard length \\
$\mathbf{4}$ & CPL:SL & Ratio caudal peduncle length to standard length \\
$\mathbf{5}$ & AL:SL & Ratio anal fin length to standard length \\
$\mathbf{6}$ & CL:SL & Ratio caudal fin length to standard length \\
$\mathbf{7}$ & PL:SL & Ratio pectoral fin length to standard length \\
$\mathbf{8}$ & ED:HL & Ratio eye diameter to head length \\
$\mathbf{9}$ & PRO:HL & Ratio pre-orbital length to head length \\
$\mathbf{1 0}$ & JL:HL & Ratio jaw length to head length \\
$\mathbf{1 1}$ & POO:HL & Ratio postorbital length to head length \\
$\mathbf{1 2}$ & SDFR & Soft dorsal fin rays \\
$\mathbf{1 3}$ & SCFR & Soft caudal fin rays \\
$\mathbf{1 4}$ & SAFR & Soft anal fin rays \\
$\mathbf{1 5}$ & SVFR & Soft ventral fin rays \\
$\mathbf{1 6}$ & SPFR & Soft pectoral fin rays \\
$\mathbf{1 7}$ & DS & Dorsal spine \\
$\mathbf{1 8}$ & PoDFR & Pattern on dorsal fin rays \\
\hline
\end{tabular}

Phylogenetic tree reconstruction began with deciding morphological characters from OTU (Operational Taxonomy Unit). The used characters consisted of ratio between two morphometric measurements, fin rays, and pattern on dorsal fin rays. The total number of characters for phylogenetic analysis was 18 pieces (Table 1). The observed morphology characters transformed into multi-state characters and symbolized as 0,1 , and 2 . The symbol of 0 indicated as primitive characters that present in outgroup species. Symbols of 1 and 2 indicated derived characters present in ingroup species. The meaning of the symbols summarized in Table 2.

Table 2. The meaning of the character symbols

\begin{tabular}{ccc}
\hline No & Symbol & Annotation \\
\hline 1 & 0 & Short or less \\
\hline 2 & 1 & Medium \\
\hline 3 & 2 & Long or plenty \\
\hline
\end{tabular}

All the matrix data arranged in the form of nexus that consists of taxa block, character block, and PAUP block. The reliability of the tree estimated from consistency index (CI). The evolutionary relationship of Labridae estimated from character changes in phylogenetic tree. The evolutionary relationship estimated through phylogenetic tree which reconstructed based on maximum parsimony algorithm in PAUP software (Swofford \& Sullivan, 2003). The branching polarity estimated by comparing the samples with Acanthurus maculiceps from Acanthuridae as an out-group species. The reliability of branching pattern improved by applying 1000 bootstraps pseudo-replicates.

\section{RESULT AND DISCUSSION}

The phylogeny of marine ornamental fish within the Labridae family collected in Taman Manalusu Garut and Ujung Genteng Sukabumi illustrated in Figure 2. 


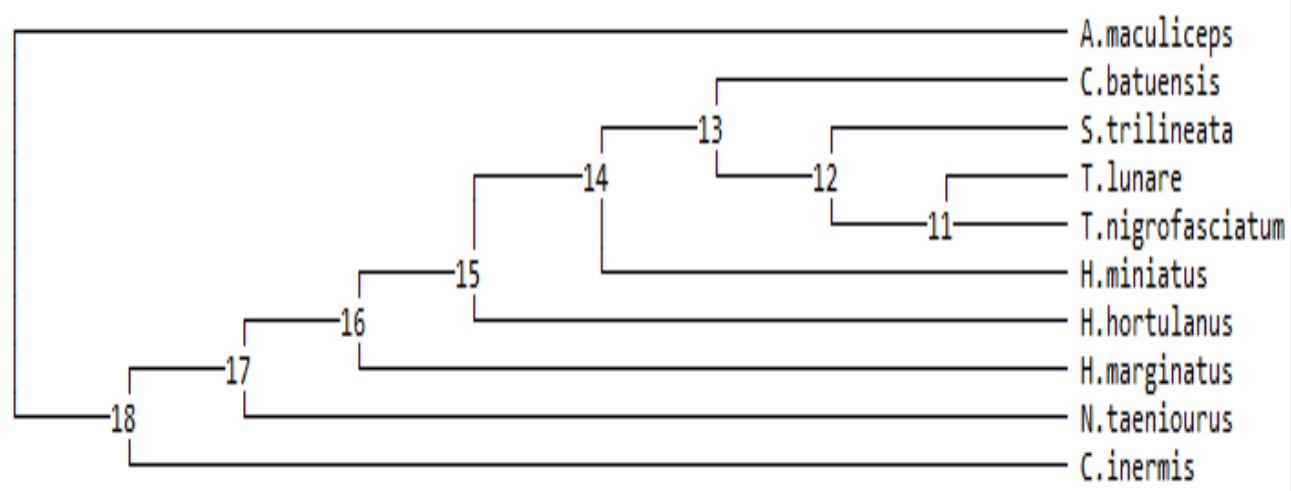

Figure 2. The phylogenetic tree shows relationships of marine ornamental fish species under Labridae

The phylogenetic tree, which usually called cladogram, has a consistency index (CI) of 0.563 with steps length of 48 and 13 out of 18 characters were parsimony informative. The tree in Figure 2 indicated that all species under Labridae formed a monophyletic clade or monophyletic group compared to Acanthurus maculiceps as an outgroup species as shown in node number 18 .
The separation of Labridae from $A$. maculiceps was due to Labridae has derived characters that evolved from primitive characters in their ancestor. The evolution of characters shown in Figure 3. Character changes between nodes might occur through reversal or non-reversal mutation as indicated by different colors in Figure 3.

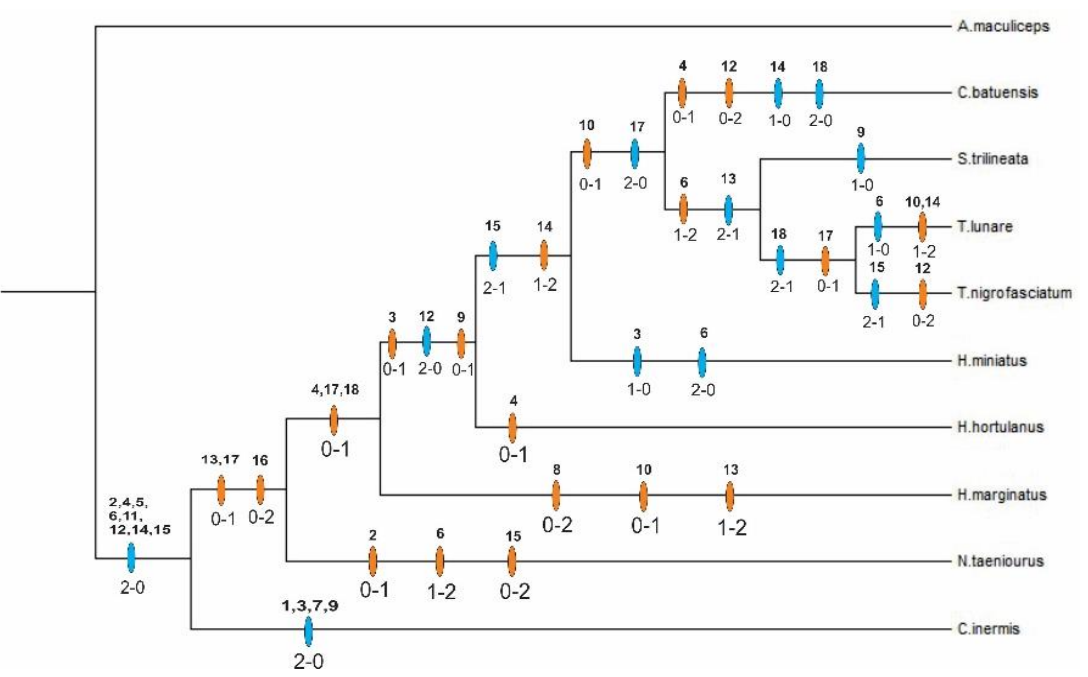

Figure 3. Cladogram showing character changes among nodes

The CI value of 0.563 indicated that the low homoplasy observed in characters during cladogram reconstruction. It has explained by (Arbi, 2016) that CI value close 1 means that the homoplasy level was low. It supported by high number of parsimonious characters (13 out of 18 characters were parsimony informative). Both data proved that the cladogram was the most parsimonious tree, means that the tree was reliable.
Low level of morphological homoplasy also reported in Drosophila melanogaster (Klingenberg \& Gidaszewski, 2010) and Scorpion (Klußmann-Fricke et al., 2012). Similar results as observed in this study and the study from (Klingenberg \& Gidaszewski, 2010) and (Klußmann-Fricke et al., 2012) was reasonable because all the studies used morphometric character during cladogram reconstruction although used different objects. 
However, our result was different from a study by Mueller et al. (2004). Here, we observed low morphological homoplasy, while (Mueller et al., 2004) reported high-level homoplasy in morphological characters of plethodontid Salamander. The difference between our study to those previous studies could be due to different characters were used. We used morphometric and meristic characters, while (Mueller et al., 2004) used tongue characters. Based on the present study and previous studies from (Klingenberg \& Gidaszewski, 2010), (Klußmann-Fricke et al., 2012), and (Mueller et al., 2004) can be assumed that different morphology characters might different level of homoplasy when they used in the phylogenetic study.

Low homoplasy can also be an indicator that similarities occurred among members of Labridae, as observed in this study indicated homolog characters of species that belong to the same ancestor. According to (Szucsich \& Pass, 2008), homolog characters are primitive characters that shared by all descendant of an ancestor and referred to as symplesiomorphic characters.

Homoplasy indicates analog characters observed in different lineages. It has resulted from convergent evolution among independent lineages. (Klingenberg \& Gidaszewski, 2010), explained that similar or identical appearance among independent lineages referred to as homoplasy.

The cladogram in Figure 2 showed the monophyly of all members of the Labridae compared to A. maculiceps as the outgroup species. This monophyly indicated that A. maculiceps was primitive species with plesiomorphic characters, while Labridae was advance group with derived characters. The clear separation of all species within Labridae to A. maculiceps proved that the selection $A$. maculiceps was correct. It was due to $A$. maculiceps shared many primitive characters with the species within Labridae because all labrid species and A. maculiceps are in the same order that is Perciformes. It has explained earlier by (Rohland et al., 2007) and (Springer et al., 2003) that a reliable branching topology and evolutionary relationship among closely related species gained through correct selection of outgroup species. They suggested that the best outgroup comes from close related taxa to taxa under study.

A clear separation between Labridae and $A$. maculiceps (Acanthuridaae) as observed in Figure 2 proved that phylogenetic classification might support conventional classification from Linnaeus which mostly based on morphological similarities without considering the evolution of the similar characteristics. A similar result also reported on fish species under genus Chaetodon (Littlewood et al., 2004). The result of this study and (Littlewood et al., 2004) study proved the importance of carefulness and preciseness in choosing morphological characters to obtain congruence results between traditional and cladistic classification.

The separation between nodes, as shown in Figure 3 occurred because of the evolution of the characters. Character's evolution divided into two types. The first type called a reversal mutation, while the second one referred to as non-reversal mutation. Both types of mutations showed a different color in Figure 3. It was following Campbell et al. (2008) that reversal and non-reversal mutation might observe during species evolution.

Character changes among Labridae nodes were as follow. Node 18 that directs to Acanthurus maculiceps proved that Acanthurus maculiceps was primitive species with plesiomorphic characters. A. maculiceps separated to ingroup (Labridae) by derived or eight apomorphic characters or referred to as synapomorphic characters. these characters include character number 2 (standard length: body depth), 4 (standard length: caudal peduncle length), 5 (standard length: anal length), 6 (standard length: caudal length), 11 (head length: jaw length), 12 (head length: jaw length), 14 (anal soft fin ray), and character number 15 (ventral soft fin ray).

Node number 18 diverged into two groups of descendants. The first group only consisted of Cheilio inermis. The second group formed by all eight remaining species. $C$. inermis separated from the second group by having four apomorphic characters. These were character 1 (standard length: body depth), character 3 
(standard length: ventral length), character 7 (standard length: pectoral length), and character 9 (head length: postocular). The second group separated from $C$. inermis by having synapomorphic characters as follow; character 13 (caudal soft fin ray), character 16 (pectoral soft fin ray), and character 17 (dorsal soft fin ray).

Node 17 can be separated into Novaculichthys taeniourus by character 2 (standard length: dorsal length), character 6 (standard length: caudal length) and character 15 (ventral soft fin ray). Node 17 can be separated into node 16 by character 4 (standard length: caudal peduncle length), character 17 (dorsal fin ray), and character 18 (pattern on dorsal fin ray).

Node 16 can be separated into Halichoeres marginatus by character 8 (head length: eye diameter), character 10 (head length: jaw length) and character 13 (caudal soft fin ray). Node 16 can be separated into node 15 by character 3 (standard length: ventral length), character 9 (head length: preocular), and character 12 (dorsal soft fin ray).

Node 15 can be separated into Halichoeres hortulanus by character 4 (standard length: caudal peduncle length). node 15 can be separated into node 14 by character 14 (anal soft fin ray), and character 15 (ventral soft fin ray). Node 14 can be separated into Halichoeres miniatus by character 3 (standard length: ventral length). Node 14 can be separated into node 13 by character 10 (head length: jaw length) and character 17 (dorsal soft fin ray).

Node 13 can be separated into Coris batuensis by character 4 (standard length: caudal peduncle length), character 12 (dorsal soft fin ray), character 14 (anal soft fin ray) and character 18 (pattern on dorsal fin ray). Node 13 can be separated into node 12 by character 6 ( standard length: caudal length) and character 13 (caudal soft fin ray).

Node 12 can be separated into Stethojulis trilineata by character 9 (head length: preocular). Node 12 can be separated into node 11 by character 17 (dorsal soft fin ray) and character 18 (pattern on dorsal fin ray).

Node 11 can be separated into Thalassoma nigrofasciatum by character 12 (Dorsal fin ray) and character 15 (Pattern on dorsal fin ray). Node 11 can be separated into Thalassoma lunare by character 6 (standard length: caudal length), character 10 (head length: jaw length), and character 14 (anal soft fin ray).

Character changes or mutation among nodes was also reported on Crustacea (Hernawati et al., 2013). Monophyly, all of species under Pomacentridae, was due to that they shared derived or synapomorphic characters. The phenomena also occurred during nodes, sister taxa, and group formation. On the one hand, the separation of species occurred because each has an autapomorphic character. On the other hand the unity among species (clade formation) due to that they shared either apomorphic or plesiomorphic characters. (Szucsich \& Pass, 2008) also, (Mueller et al., 2004) stated that the present synapomorphic characters in all descendants might lead to clade formation.

\section{CONCLUSION}

The obtained cladogram was a parsimonious tree with a high consistency index and low homoplasy. Labridae formed monophyletic clade compared to Acanthurus maculiceps, and Cheilio inermis was basal species while the others derived species.

\section{ACKNOWLEDGMENTS}

We thank Directorate of Research and Public Services (DRPM) Ministry of Research, Technology, and Higher Education of the Republic of Indonesia for funding through research scheme Penelitian Dasar Unggulan Perguruan Tinggi (PDUPT) which granted to Dr. Agus Nuryanto, S.Si., M.Si., Dr. Pi. Dian Bhagawati, M.Si., and Drs. Kusbiyanto, M.Si. Our gratitude delivered to Research and Public Services Institute and Faculty of Biology, Universitas Jenderal Soedirman for the facility during the research. We thank peoples who help during the field trips and laboratory works. Our gratefulness gave to the reviewer(s) who have provided suggestions and input to improve the scientific quality of this paper.

\section{REFERENCES}

Almada VC, Almada F, Henriques M, Santos 
RS, Brito A. 2002. On the phylogenetic affinities of centrolabrus trutta and centrolabrus caeruleus (Perciforms: Labridae): molecular and meristic evidence. Arquipel Life and Marine Sciences. vol 19: 85-92.

Allen GR, and Erdmann MV. 2012. Reef fishes of the East Indies. Perth: University of Hawaii Press. p. 1292.

Arbi UY. 2016. Analisis kladistik berdasar karakter morfologi untuk studi filogeni: contoh kasus pada conidae (Gastropoda: Mollusca). Oceana. vol 63(3): 54069. doi: https://doi.org/10.1017/CBO97811074153 24.004.

Arnal C, Verneau O, Desdevises Y. 2006. Phylogenetic relationships and evolution of cleaning behaviour in the family labridae: importance of body colour pattern. Journal of Evolutionary Biology. vol 19(3): 755-763. doi: https://doi.org/10.1111/j.1420-

9101.2005.01059.x.

Baliga VB, and Law CJ. 2016. Cleaners among wrasses: phylogenetics and evolutionary patterns of cleaning behavior within labridae. Molecular Phylogenetics and Evolution. vol 94:424-435. doi: https://doi.org/10.1016/j.ympev.2015.09.0 06.

Beldade R, Heiser JB, Robertson DR, Gasparini JL, Floeter SR, Bernardi G. 2009. Historical biogeography and speciation in the creole wrasses (Labridae, Clepticus). Marine Biology. vol 156(4): 679-687. doi: https://doi.org/10.1007/s00227-008-11185.

Bernal MA, and Rocha LA. 2011. Acanthurus tractus Poey, 1860, a valid western Atlantic species of surgeonfish (Teleostei, Acanthuridae), distinct from Acanthurus bahianus Castelnau, 1855. Zootaxa. vol 2905(1): 63-68. doi: http://dx.doi.org/10.11646/zootaxa.2905.1 .5 .

Campbell NA, Reece JB, Taylor MR, Simon EJ, Dickey JL. 2008. Biology: concept and connection. $6^{\text {th }}$ ed. San Francisco: Benjamin Cummings. p. 928

Carpenter K, Williams J, Santos M. 2017.
Acanthurus albimento, a new species of surgeonfish (Acanthuriformes: Acanthuridae) from Northeastern Luzon, Philippines, with comments on zoogeography. Journal of the Ocean Science Foundation. vol 25(2017):33-46. doi: https://doi.org/10.5281/zenodo.291792.

Choat JH, klanten OS, Van Herwerden L, Robertson DR, Clements KD. 2012. Patterns and processes in the evolutionary history of parrotfishes (Family Labridae). Biological Journal of the Linnean Society. vol 107(3): 529-557. doi: https://doi.org/10.1111/j.10958312.2012.01959.x.

Froese R, and Pauly D. 2019. FishBase. World wide web electronic publication. www.fishbase.org. Assessed May 2019.

Floeter SR, Bender MG, Siqueira AC, Cowman PF. 2018. Phylogenetic perspectives on reef fish functional traits. Biological Reviews. vol 93(1): 131-151. doi: https://doi.org/10.1111/brv.12336.

Hernawati RT, Nuryanto A, Indarmawan. 2013. Analysis of species richness and the relationships of the Crustaceans (Decapods) at Cijalu. Jurnal Pembangunan Pedesaan. vol 13(1):39-48. Hoeksema BW. 2007. Delineation of the IndoMalayan centre of maximum marine biodiversity: The Coral Triangle. pp. 117178. doi: https://doi.org/10.1007/978-14020-6374-9_5.

Kamarudin KR, and Esa Y. 2009. Phylogeny and phylogeography of Barbonymus schwanenfeldii (Cyprinidae) from Malaysia inferred using partial cytochrome B MtDNA gene. Journal of Tropical Biology and Conservation. vol 5(1):1-13.

Klingenberg CP, and Gidaszewski NA. 2010. Testing and quantifying phylogenetic signals and homoplasy in morphometric data. Systematic Biology. vol 59(3):245261.

doi: https://doi.org/10.1093/sysbio/syp106.

Klußmann-Fricke BJ, Prendini L, and Wirkner CS. 2012. Evolutionary morphology of the hemolymph vascular system in scorpions: a character analysis. Arthropod Structure 
and Development. vol 41(6):545-560. doi: https://doi.org/10.1016/j.asd.2012.06.002.

Littlewood DTJ, McDonald SM, Gill AC, Cribb TH. 2004. Molecular Phylogenetics Of Chaetodon and the Chaetodontidae (Teleostei: Perciformes) with reference to morphology. Zootaxa. vol 779(1): 1. doi: https://doi.org/10.11646/zootaxa.779.1.1.

Liu SYV, Ho HCH, and Dai CF. 2013. a new species of Pomacentrus (Actinopterygii: Pomacentridae) from Micronesia, with comments on its phylogenetic relationships. Zoological Studies. vol 52(1):2-9.

doi: https://doi.org/10.1186/1810-522X-52-6.

Mayunar. 1996. Jenis-Jenis ikan karang ekonomik penting sebagai komoditi ekspor dan prospek budidayanya. Oseana. vol XXI(3): 23-31.

Mueller RL, Macey JR, Jaekel M, Wake DB, and Boore JL. 2004. Morphological homoplasy, life history evolution, and historical biogeography of Plethodontid Salamanders inferred from complete mitochondrial genomes. Proceedings of the National Academy of Sciences of the United States of America. vol 101(38): 13820-13825.

doi: https://doi.org/10.1073/pnas.0405785101.

Murakami M, Matsuba C, Fujitani H. 2001. The maternal origins of the triploid Ginbuna (Carassius auratus langsdorfi): Phylogenetic relationships within the $C$. auratus taxa by partial mitochondrial DLoop sequencing. Genes and Genetic Systems. vol 76(1): 25-32. doi: https://doi.org/10.1266/ggs.76.25.

Naeem M, Zuberi A, Salam A, Ali M, Riaz-ulHaq M, Khalid M, Mehreen M, Nasir MF, Rasool SA, Ishtiaq A. 2011. Some morphometric relationships of hatchery reared male population of Oreochromis mossambicus from Pakistan. African Journal of Biotechnology. vol 10(75): 17362-17366.

doi: https://doi.org/10.5897/AJB11.1846.

Parenti P, and Randall JE. 2011. Checklist of the species of the families Labridae and Scaridae: an update. Smithiana Bulletin. vol 13: 29-44.
Rohland N, Malaspinas AS, Pollack JL, Slatkin M, Matheus P, and Hofreiter M. 2007. Proboscidean mitogenomics: chronology and mode of elephant evolution using mastodon as outgroup. PLoS Biology. vol 5(8): $\quad$ 1663-1671. doi: https://doi.org/10.1371/journal.pbio.00502 07.

Sabour W, Saad A, and Jawad L. 2014. First Record of the yellowspotted puffer Torquigener Flavimaculosus Hardy \& Randall. The Mediterranean Sea Coasts of Syria. vol 36: 29-34. doi: https://doi.org/10.1285/i15910725v36p29.

Santini F, Sorenson L, and Alfaro ME. 2016. Phylogeny and biogeography of hogfishes and allies (Bodianus, Labridae). Molecular Phylogenetics and Evolution. vol 99:1-6. doi:

https://doi.org/10.1016/j.ympev.2016.02.0 11.

Sasaki T, Kartavtsev YP, Chiba SN, Uematsu T, Sviridov VV, Hanzawa N. 2007. Genetic divergence and phylogenetic independence of far eastern species in subfamily Leuciscinae (Pisces: Cyprinidae) inferred from mitochondrial DNA analyses. Genes and Genetic Systems. vol 82(4): 329-340. doi: https://doi.org/10.1266/ggs.82.329.

Smith KF, Behrens MD, Max LM, Daszak P. 2008. US Drowning in unidentified fishes: scope, implications, and regulation of live fish import. Conservation Letters. vol 1(2):103-109. doi: https://doi.org/10.1111/j.1755263x.2008.00014.x.

Sorenson L, Allen GR, Erdmann MV, Dai CF, Liu SYV. 2014. Pleistocene Diversification Of The Pomacentrus Coelestis Species Complex (Pisces: Pomacentridae): Historical Biogeography And Species Boundaries. Marine Biology. vol 161(11): 2495-2507. doi: https://doi.org/10.1007/s00227-014-25218.

Springer MS, Murphy WJ, Eizirik E, O’Brien SJ. 2003. Placental Mammal Diversification And The CretaceousTertiary Boundary. Proceedings of the 
National Academy of Sciences of the United States of America. vol 100(3): 1056-1061.

doi: https://doi.org/10.1073/pnas.0334222100.

Swofford DL, and Sullivan J. 2003. Phylogeny inference based on parsimony and other methods using PAUP*. The phylogenetic handbook: a practical approach to DNA and protein phylogeny. Cambridge:
Cambridge University Press. vol 7: 160206.

Szucsich NU, and Pass G. 2008. Incongruent phylogenetic hypotheses and character conflicts in morphology: the root and early branches of the hexapodan tree. Mitt. Dt. Ges. Allg. Angew. Entomol. vol 16: 415430. 